\title{
Real Exchange-Rate Behaviour under Fixed and Floating Exchange Rate Regimes
}

James R. Lothian

Fordham University, lothian@fordham.edu

Cornelia H. McCarthy

Fordham University

Follow this and additional works at: https://fordham.bepress.com/crif_working_papers

Part of the Finance and Financial Management Commons

\section{Recommended Citation}

Lothian, James R. and McCarthy, Cornelia H., "Real Exchange-Rate Behaviour under Fixed and Floating Exchange Rate Regimes" (2001). CRIF Working Paper series. 15.

https://fordham.bepress.com/crif_working_papers/15 


\title{
Real Exchange-Rate Behaviour under Fixed and Floating Exchange Rate Regimes
}

\author{
James R. Lothian
}

Fordham University, Graduate School of Business Administration New York, NY 10023, USA

tel. 1212636 6147; fax 1212765 5573; emails lothian@fordham.edu; lothian@indigo.ie

$$
\text { and }
$$

Cornelia H. McCarthy**

Fordham University, Graduate School of Business Administration New York, NY 10023, USA

tel. 1212636 6149; fax 1212765 5573; email comccarthy@fordham.edu

May 2001

Manchester School, February 2002 forthcoming 
* The authors wish to thank Liam Gallagher, Patrick Honahan, two anonymous referees of this journal and participants at the North American Economic and Finance Association Sessions at the 1999 ASSA Meetings in New York for their comments. 


\begin{abstract}
In this paper we examine the stability of the real exchange rate and the macroeconomic effects of alternative exchange-rate regimes, including currency union, on real exchange-rate behaviour. We focus on the Irish punt in order to exploit its diversity of experience over different nominal exchange rate regimes. We make both temporal and cross-country comparisons of real-exchange-rate stability for the Irish punt with sterling, the US dollar and the German mark. We reach two conclusions on the basis of our results. The first is that for Ireland, as for most other countries, purchasing power parity provides a reasonably good description of actual exchange rate behaviour over the long run. Our second principal conclusion concerns regime effects. Currency union appears to matter. The real exchange rates we analyse are unambiguously less variable under currency union than under alternative exchange-rate systems. Otherwise, however, we find no clear-cut differences in behaviour across regimes.
\end{abstract}

JEL Classification: F31 


\section{Real Exchange-Rate Behaviour under Fixed and Floating Exchange Rate Regimes}

The research that we have conducted and that we report on here centres on two key issues in exchange-rate economics: the stability of the real exchange rate and the macroeconomic effects of alternative exchange-rate regimes, including currency union, on real exchange rate behaviour. To study regime effects, we focus on Ireland. Our major reason for doing so is Ireland's rather unique experience in terms of exchange rate regimes. Within this century, Ireland has gone from being linked to the United Kingdom politically and via currency union, to being linked via currency union alone, to, in recent decades, a floating exchange rate of varying degrees of flexibility relative to sterling.

Relative to other countries it has had much the same experience as the UK -- episodes of adherence to the gold standard earlier in the century, the controlled rates of the later inter-war and World War II years, the Bretton-Woods peg and finally the current float. In the case of EU countries, the last has of course been replaced by the ERM and within the next two years will itself be replaced by a new currency union.

To exploit this diversity of experience we therefore make both temporal and cross-country comparisons of real-exchange-rate stability. The data that we use in this analysis are annual exchange rates of the Irish punt relative to the pound sterling, the German mark and the US dollar over the period 19221998 and the corresponding annual consumer price indexes, or in the case of the UK, the retail price index. The methods that we use range from simple graphical analysis, to unit root tests for real exchange rates and Chow-type tests of temporal and spatial stability.

The key theoretical concept underlying both the analysis of regime effects and real exchange rate behaviour more generally is the purchasing power parity theorem. ${ }^{1}$ In the simplest version of purchasing power parity, the price level in one country is equal to the product of the price level in the other and the nominal exchange rate between their currencies. The real exchange rate -- the nominal exchange rate divided by the ratio of the two countries' price levels -- is therefore treated as a constant. This is posited

1. A variety of theoretical models, ranging from simple open-economy versions of the quantity theory of money to Lucas's (1982) two-country, cash-in-advance model, give rise to purchasing power parity as an equilibrium position. 
to be the case, moreover, regardless of the exchange-rate regime. The regime is viewed as being neutral,

only affecting the behaviour of nominal economic variables in the countries involved, and not the behaviour of the real.

How well this theoretical model accords with experience therefore depends importantly on how the real exchange rate actually behaves under the two types of regimes -- whether, if not literally constant (as it almost certainly is not), the real exchange rate returns to some stable value over time under the two regimes and whether this pattern of movements is itself invariant to the regime. Studies of real exchange rate behaviour over the past decade have reached quite different conclusions about these questions. ${ }^{2}$ According to one view, the traditional explanation of exchange rate behaviour based on purchasing power parity ceased to be of use following the shift to floating exchange rates in the early 1970s. Real exchange rates on this account became excessively variable and rather than tending to revert to stable equilibrium values behaved randomly. Recent findings have been much more supportive of PPP, but these too have been called into question. One objection that has been raised centres on the possible adverse econometric effects of data heterogeneity, of combining data for varied exchange rate regimes, and of the applicability to the current float of results obtained with such data.

\section{Theoretical Considerations}

To understand the relationship between nominal and real exchange rates and, in turn, their relationship to the concept of purchasing power parity, consider the following identity defining the real exchange rate in terms of its nominal-rate and the price-level components:

$$
\mathrm{q}_{\mathrm{t}} \equiv \mathrm{e}_{\mathrm{t}}-\mathrm{p}_{\mathrm{IRL}, \mathrm{t}}+\mathrm{p}_{\mathrm{FOR}, \mathrm{t}}
$$

2. The literature alluded to immediately below is reviewed in the next section of this paper. For recent surveys of this literature see Edison, et al. (1997), Froot and Rogoff (1995), Rogoff (1996), and Taylor (1995). On various aspects of Irish exchange rate behavior see Fountas and Wu (1995), Gallagher and Kavanagh (2000), Honahan (1997), Leddin and O' Leary (1995), Thom (1989) and Wright (1993, 1994). 
where $\mathrm{q}_{\mathrm{t}}$ is the log real exchange rate, $\mathrm{e}_{\mathrm{t}}$ is the log nominal exchange rate, the domestic currency price of a unit of the foreign currency, and $\mathrm{p}_{\mathrm{IRL}, \mathrm{t}}$ and $\mathrm{p}_{\mathrm{FOR}, \mathrm{t}}$ are the $\log$ Irish and foreign price levels, respectively. If purchasing power parity held perfectly, $\mathrm{q}_{\mathrm{t}}$ would equal a constant, call it $\mathrm{q}$, and we could rewrite (1) as:

$$
\mathrm{p}_{\mathrm{FOR}, \mathrm{t}}+\mathrm{e}_{\mathrm{t}}=\mathrm{q}+\mathrm{p}_{\mathrm{IRL}, \mathrm{t}} \text {. }
$$

In a fixed-exchange-rate regime, the nominal exchange rate by definition is constant, and in the limiting case of a common currency equal to unity. Under these conditions, equation (2) becomes a relation linking the price levels in the two countries, the macroeconomic analogue of the law of one price. In a floatingexchange-rate regime, in contrast, equation (2) describes the relation between the two countries' price levels and the nominal exchange rate, or alternatively between the exchange-rate adjusted price level in the one country and the actual price level in the other.

One set of conditions under which PPP will work well empirically is if money-supply growth in one of the countries has been both rapid and well in excess of money-supply growth in the other country. The other situation in which PPP will hold tolerably well is if real factors have effects that are merely persistent but not truly permanent. In such circumstances, real shocks will not matter to any great extent when the data are viewed over long time horizons. This latter possibility, which at first glance seems to be simply a truism, does have some theoretical and empirical appeal. It is one of the implications of the neo-classical growth model. It also appears to be a characteristic of very long-term data such as the various relative price series investigated by Froot, Rogoff and Kim (1995) and the nearly four-century long guildersterling real exchange rate data studied by Lothian (1998b). Perhaps more impor tant such behaviour also appears to be a feature of US dollar real exchange rate behaviour under the current float. (Lothian, 1998a)

\section{I.A. Recent Studies}

When the Bretton Woods system broke down in the early 1970s, the exchange-rate theory that we have just reviewed was the prevailing paradigm. As the 1980 s drew to a close, very nearly the opposite 
was true. Purchasing power parity was viewed as largely, if not totally, discredited and the real exchange rate as highly unstable.

More recent analyses using long-term historical data has, however, painted a much more favourable picture. These studies have pointed to mean-reverting behaviour of one sort or another for a wide variety of real exchange rates and over a wide variety of time periods. (Diebold, Husted and Rush, 1991; Johnson, 1993; Lothian, 1990; Lothian and Taylor, 1996; and Taylor, 1996). As originally thought, therefore, purchasing power parity does appear to have been a reasonably good long-term first approximation. Deviations from PPP are persistent, but in the end largely (though probably not completely) disappear.

The bulk of this evidence has come from examination of long historical data sets. Some researchers have questioned the applicability of the findings reported in those studies to behaviour under the current float. The general issue here is a possible difference in the behaviour of real exchange rates across exchange-rate regimes. One such alleged effect is faster adjustment of real exchange rates to shocks under floating exchange rates than under fixed. The idea is that the principal set of shocks under floating is to nominal exchange rates and that these will adjust more rapidly than price levels which bear the brunt of the adjustment under fixed rates. Studies of real exchange rate mean reversion using historical time series data, it is claimed, as a result have been subject to aggregation bias. This in turn, it is argued, has vitiated the findings of such studies. Plausible as this characterization at first glance appears to be, it has gone largely untested.

\section{Empirical Results}

During the course of the 77 years spanned by our data, the exchange rate regime linking Ireland and the United Kingdom changed dramatically. In 1922 at the start of the data period, Ireland had just gained a substantial measure of political independence from the United Kingdom. Monetarily, however, the ties between the two countries stayed as close as ever. ${ }^{3}$ From 1922 to 1942 the Irish currency was

3. For a discussion of the operations of the Currency Commission, the Irish Central Bank and the monetary links between Ireland and the United Kingdom after 1922 see Honahan (1997) and ó Gráda and 
controlled by the Currency Commission made up of representatives from private banks and from the government. Under the Currency Commission the Irish pound could be exchanged one-for-one with sterling. In 1943 the Irish Central Bank was established but, as discussed in Honahan (1997), it functioned until 1979 as a currency board maintaining parity with sterling throughout this period. Therefore, the currency union that had begun in 1826 remained in tact until 1979, with the result that policy in Ireland was effectively still being determined in London. In 1973 Ireland was admitted into the European Union -at that point still called European Economic Community -- and in 1979 became a part of the European Exchange Rate Mechanism (ERM). The punt at that point became linked to the DM and the other EU currencies but floated relative to the rest of the world. The United Kingdom, in contrast, only became part of the ERM in October 1990 and left a scant two years later in September 1992.

How monetarily independent Ireland and the UK actually became post-1979 is, however, an empirical question. Initially, at least, there were close real-side links between the two economies and these in turn, as we have noted, had important implications for Irish policy. Irish membership in the ERM was accompanied by a Central Bank of Ireland policy of exchange-rate pegging, in which interest-rate policy was geared to movements in the trade-weighted average punt exchange rate. With the UK accounting for roughly $40 \%$ of Irish exports in the earlier years following the severing of punt-sterling parity, the two currencies clearly could not wander too far apart.

\section{II.A. Data overview}

The price data that we use are annual averages of monthly consumer price indexes for Ireland, Germany, and the United States and of the monthly retail price index for the United Kingdom from 1922 to $1998 .{ }^{4}$ Exchange rates are Irish versus foreign currency exchange rates derived as cross rates from the

\section{O’Rourke (1994).}

4. Data for Irish and German consumer prices came from European Historical Statistics, for the period prior to 1949. Data for UK retail prices came from Feinstein (1975) and from the International Financial Statistics on CD ROM thereafter. Data for the dollar exchange rate of Germany and the United Kingdom for the years prior to 1949 were provided by Phillipe Jorion. Data for the period ther eafter came from the International Financial Statistics on CD ROM. The price level and exchange rate for Germany 
corresponding US dollar series, or in the case of the UK, assumed to be unity until 1970. The choice of price series was dictated by data availability. PPP might, however, be expected to hold better for PPIs than CPIs since the former are likely to be more heavily weighted with tradable goods.

Shown in Figures 1 through 3 are plots of the logs of the exchange rate-adjusted price levels in the three countries against the log Irish price level and the three corresponding log real exchange rates. What is most immediately apparent in these first three charts is the difference between the behaviour of the price levels and the behaviour of the real exchange rates. The price levels in all instances have substantially, and for the most part rather similar, upward trends. The real exchange rates in contrast appear almost trendless. On this purely visual level, therefore, the principal implications of purchasing power parity appear to be borne out. The law of one price seems to hold quite well over the long term, while the real exchange rate over such time horizons appears quite stable in comparison to the price series.

Two features of the real exchange rate behaviour exhibited in these charts deserve further comment. The first is the much lower variability of the punt-sterling real exchange rate than of either the punt-DM or the punt-dollar rate. The second is the persistent and often substantial movements in all three series. For the most part these fluctuations appear consistent with mean reversion, but given their longlived nature we clearly have relatively few independent episodes for testing these inferences.

Shown in Table 1 are means and standard deviations of the price series and the real exchange rates for both the full period and for var ious subperiods. As the charts indicated, the punt-sterling real exchange rate is by far the least variable of the three throughout the period, as well as in most of the subperiods viewed individually. This continued to be true, moreover, even after 1979, although the extent of the disparity vis-à-vis the other two countries eventually became much less than in earlier periods and in the 1993-98 subperiod actually was reversed, with punt-sterling variability now exceeding the variability of the other two rates. ${ }^{5}$ Comparing real-exchange-rate variability across subperiods of floating and fixed

begin in 1924 .

5. As we point out above, there are two possible reasons for this continued lower variability of the punt-sterling real exchange rate. One is the strong real-side links between the two countries; the other is the Central Bank of Ireland's policy during much of the period of pegging the punt to a trade weighted and hence sterling-dominated exchange rate. 
exchange rates we see greater variability under floating rates than under fixed. In all three cases variability is greater during the 1973-98 period than in the immediately preceding two decades. The first was of course a period during which all three exchanges at least for a time floated; the second, a period of fixed or pegged rates depending upon the currencies involved. For the UK and US we see very low variability in the subperiod from 1922 to 1930, a period during which both countries, as Ireland, were for the most part on the gold standard. During the rest of the thirties when gold had broken down real exchange rate variability was markedly higher for both the United States and Germany. For the UK, real rate variability only becomes relatively high after 1979, when the currency union linking sterling and the punt ended.

Additional evidence on cross regime differences is provided by the results of the dummy variable regressions reported in Table 2. The dependent variables in these regressions were the standard deviations of the three punt $r$ eal exchange $r$ ate for a somewhat finer division of subperiods than those used in Table $1 .^{6}$

We use two dummy variables here. The first, DFIXED, takes the value one for all periods of fixed exchange rates including the period of currency union between Ireland and the UK and is zero otherwise. The second, DUNION, takes the value one only for the latter period and is zero otherwise. Any difference between floating-rate and fixed-rate regimes per se is reflected in the coefficient of DFIXED. The full effect of a currency union relative to floating rates is therefore found as the algebraic sum of these two coefficients. In the second of these regressions we also included a dummy variable for World war II. We ran these regression using pooled data for the three exchange rate series combined.

Regime differences matter: the dummy for fixed exchange rate reg imes is negative and significantly different from zero at the 95 per cent level in the first regression, and still negative though only significant at a bit less than the 90 per cent level in the second. Currency union, however, matters much more. We can see this by forming linear combinations of these coefficients to get estimates of average levels of variability for the three regimes separately. For floating rates this estimate is .081 , for fixed .058 , and for

6. The subperiods were chosen to be better reflective of the differences in exchange-rate regime. These subperiods were as follows: 1922-25, 1926-31, 1932-39, 1940-45, 1946-49, 1950-59, 1960-69, 1970-72, 1973-78, 1979-86, 1987-92, and 1993-98. 
currency union .024.

These results in the main are in line with those reported by Mussa (1986). As part of his extensive analysis of the question of regime effects, he examined data for the three real exchange rates, and their corresponding nominal exchange-rate and relative-price-level components, that we study, as well as a large body of other exchange-rate and price data. Mussa's Irish data were quarterly observations for the period 1957:I to1984:III. He concluded that there were systematic differences in behaviour across regimes. As was true for the other real exchange rates he examined, the three punt real exchange rates were consistently more variable under floating than under fixed rates.

Mussa explained such cross-regime differences in terms of a monetary model with exchange-rate overshooting. In such a model, the nominal exchange rate adjusts quickly and overshoots following a monetary shock, and the relative price level adjusts slowly. In the initial part of the adjustment process, variability of nominal exchange rates and of real exchange rates increase; only later does the variability of the relative price level rise.

Figures $4 \mathrm{a}$ through $4 \mathrm{c}$ plot subperiod variances of the three real exchange rates along with their respective variance components. As monetary models imply, a higher variance of real exchange rates is accompanied by a higher variance of nominal rates under floating rates. As those models further imply, the variance of relative price levels also is higher. And, consistent with purchasing power parity, the covariance between these two components also increases. Indeed, if that were not the case, real exchange rate variability would be a substantial multip le of the levels actually reached in several of the se subperiods. One additional feature of these charts that deserves mention is the somewhat varied experience of the past two and a half decades. In each instance the increase in the variability of the real exchange rate is greater in the subperiods following the moves to floating rates - post-1973 in the case of both the US and German rates, and post-1979 in the case of the UK rate. This may in part be due to monetary shocks being greater initially; it also may be reflective of a learning process. A final point concerns the behaviour of the puntDM real exchange rate post 1979. As theory would suggest in this case, we see very much the opposite occurring -- a decrease in variability, particularly during the latter portion of the period. 


\section{II.B. Cointegration and unit root tests}

Table 3 presents econometric evidence on long-run behaviour. The particular question it addresses is the nature of the long-term relation linking the Irish and foreign-country exchange-rate adjusted price levels, whether $\mathrm{p}_{\mathrm{IRL}}$ and $\mathrm{pa}_{\mathrm{FOR}}$ share a common trend, and are therefore cointegrated.

To see what these tests entail let us consider a stochastic version of equation (2):

$$
\mathrm{p}_{\mathrm{IRL}, \mathrm{t}}=\alpha+\beta_{1} \mathrm{pa}_{\mathrm{FOR}, \mathrm{t}}+\mathrm{u}_{\mathrm{t}}
$$

where $\mathrm{pa}_{\mathrm{FOR}, \mathrm{t}} \equiv \mathrm{p}_{\mathrm{FOR}, \mathrm{t}}+\mathrm{e}_{\mathrm{t}}, \alpha$ and $\beta$ are the cointegrating coefficients and $\mathrm{u}_{\mathrm{t}}$ is the error term. We follow Lothian (1998b) and impose the constraint of $\beta=1 .^{7}$ This allows us to test for the cointegration of the price levels by testing the stationarity of the real exchange rate in the following form:

$$
\mathrm{q}_{\mathrm{t}}=\lambda \mathrm{q}_{\mathrm{t}-1}+\eta_{\mathrm{t}}
$$

A necessary condition for the price levels to be cointegrated is that each price series is integrated of the same order. To demonstrate this we first conduct augmented Dickey-Fuller tests and Phillips-Perron tests for both the levels and first differences of the price variables. These results are presented in the top portion of Table $3 .^{8}$ The Phillips-Perron tests have the particular advantage of being robust in the presence of heteroskedasticity, which over this long historical period, when so much else has changed, is liable to pose a problem. The results for the three exchange-rate adjusted price series and the Irish price series were very similar. In each instance the unit root null could be rejected for the first differences but not for the levels. The tests suggest therefore that all four variables are I(1), and hence integrated of the same order.

7. In an alternative two step procedure to test if $\mathrm{p}_{\mathrm{IRL}, \mathrm{t}}$ and $\mathrm{pa}_{\mathrm{FOR}, \mathrm{t}}$ are cointegrated would be to estimate (3) using OLS and test if a first order autoregressive process of the residuals had a coefficient of $\lambda=1$. A value of $\lambda$ significantly less than unity would provide evidence of stationarity and hence price-level convergence. The related question of whether $\beta$ itself was unity could then be addressed.

8. ADF is the augmented Dickey Fuller unit root test with the appropriate number of lagged differences determined by the BIC criterion. PP is Phillips-Perron unit root test with the window width set at 3 . 
Table 3 also contains the results of tests of the stationarity of the three real exchange rates based both on augmented Dickey-Fuller tests and Phillips-Perron tests. For two out of the three - the puntdollar rate is the one exception — we reject the unit-root null at a 5\% or better significance level. For the punt-dollar rate, we reject at slightly over $10 \%$ using the ADF test but only at much higher levels using the Phillips-Perron test. Given the fixed nature of the punt-sterling nominal exchange rate over much of this time period it is possible that our punt-dollar results simply reflect the relationship between sterling and the dollar over this period. Lothian and Taylor $(1996,2000)$ have tested the sterling-dollar real exchange rate for data covering the much longer period 1791 to 1990 . They have found significant evidence of mean reversion for the sterling-dollar real exchange rate. Our weak result here for the puntdollar real exchange rate may be due to low test power and our much shorter data set.

That, however, is probably not the whole story. We ran similar tests for the dollar-sterling real exchange rate and found some evidence of stationarity. Using the ADF test, we were able to reject the unit-root null at the five per cent level; using the Phillips-Perron test, however, we were unable to reject it at even the $10 \%$ level. The behaviour of the relative price levels in Ireland and the UK therefore also seems to have mattered.

It is also interesting to compare our results with those reported in several recent papers comparing intranational and international experience. These studies have reached the quite counterintuitive conclusion that PPP holds across countries but not within countries. Such conclusions have been based on the results of unit-root tests, which gener ally have shown that it is possible to reject a unit root for real exchange rates internationally but not intranationally (see, e.g., Culver and Papell, 1999; Bayoumi and MacDonald, 1998). In contrast, our results show strong rejection of the unit-root hypothesis for Ireland vs. the UK and for Ireland vs. Germany but much weaker rejection for Ireland vs. the U.S. Our results, however, are very much in line with findings reported by Chen and Devereux (1999). Like other researcher s they reject the unit root null with the international but not with the intranational (US city) data. But when they examine the data further they find that over the long term intranational real exchange rates are remarkably stable, much more stable, in fact, than international real exchange rates. 


\section{II.C. Tests of Homogeneity}

Table 4 shows the associated AR(1) models for the three real rates and reports the results of Chow tests that we used to assess the stability of the relationships under floating rates. Since heteroskedasticity is liable to pose a problem we use heteroskedastic-consistent standard errors throughout. The alternative breakpoints were 1973 and 1979. In no instance is there a significant break in 1973, but for the punt-DM real rate we find one in 1979. Interestingly, however, the slope coefficient post-1979 is lower rather than, as has been hypothesized, higher. In contrast to the popular belief, adjustment to shocks was therefore faster under the ERM than under earlier regimes, including the 1973-1979 period in which the punt-DM rate floated. As one of the referees noted, one possible reason for this faster adjustment of the punt-DM real rate under the ERM may be the two devaluations that occurred pre-1987 and the wider bands that existed post-1993.

Table 5 reports the results of similar sets of autoregressions run on the pooled real-exchange-rate data. In the first two regressions we only include dummy variables for countries. In the first of these, the dummies are used only to allow for intercept variation; in the second they are used to allow for both slope

and intercept variation. As it turned out, the coefficients of the country dummies were generally both statistically insignificant and small in magnitude. A partial exception is the intercept dummy for the United States in the first regression. It is statistically a significant but not at all substantial in its effect.

In the third and fourth regressions in Table 5 we introduce dummy variables for the floatingexchange-rate periods. We only use a dummy variable for the slope in the third regression. In the fourth, we use dummies for both the slope and the intercept. In the fifth we use both and include the country dummies. None of the floating-exchange-rate dummies are significant. The difference that we saw in variability across countries is there fore not reflected in any broad-based difference in the pattern of adjustment to shocks. Coupled with the finding of homogeneity among countries, this suggests that our failure to reject the unit-root null for the punt-dollar rate alone was most likely a reflection of low test power rather than being due to behavioural differ ences.

\section{Conclusions}


We reach two conclusions on the basis of the results reported in this paper. The first is that for Ireland as most other countries, purchasing power parity provides a reasonably good description of actual exchange rate behaviour over the long run. Changes in nominal variables over the three quarters of a century covered by our data have been extremely large. Real exchange rates in contrast have changed comparatively little. The permanent components in these real exchange rates, as PPP predicts, must therefore be relatively small.

This is very much in line with the conclusions reached by Wright in two studies of Irish exchange rate behaviour since the institution of the ERM in 1979. In the first of these studies (Wright, 1993) he decomposes both the punt-DM and punt-sterling real exchange rates into stationary and non-stationary components. He reports a quite large stationary component for punt-DM and concludes that it most likely is mean reverting. He reports a smaller stationary component for punt-sterling, but nevertheless concludes that it may in fact also be mean-reverting. In the second paper (Wright, 1994) he applies Johansen tests to the two corr esponding nominal exchange rates and to Irish and respective other-country price levels. He concludes those cointegrating relationships exist for both country pairs that are consistent with PPP, but that this is the case only when short term interest rates are taken into account. He concludes that longrun PPP holds in both instances and attributes the significant interest-rate effects to short-term influences on the PPP relationship.

Our second major conclusion concerns regime effects. Currency union appears to matter. The real exchange rates we analyse are unambiguously less variable under currency union than under alternative exchange-rate systems. Otherwise, however, we find no clear-cut differences in behaviour across regimes. The notion that adjustments to shocks will be systematically different under floating and fixed rates and the associated conclusion that the pooling of data for the two types of regimes will lead to invalid inferences therefore remain unproven.

It is interesting to speculate with regard to the reasons for this difference in behaviour. One, which we have already mentioned, is the absence of monetary shocks within the currency union. This doubtless is a major reason why real exchange rate variability was lowest for punt-sterling over our sample period. It also may explain why variability in the other two real exchange rates has decreased over the past decade, 
particularly the variability of the punt-DM rate. Another reason for the consistently low variability of the punt-sterling rate is the close links that existed historically between the two countries' real economies. For most of the period the U.K. was Ireland's leading trading partner. Under such circumstances the influence of real shocks might be expected to be lower for Ireland vs. the UK than for Ireland versus the other two countries. This is perhaps one reason why after the dissolution of the currency union between Ireland and the UK that variability in the punt-sterling real exchange rate has remained relatively low. ${ }^{9}$

9 Gallagher and Kavanagh (2000) present evidence on the relative influence of nominal and real shocks on these three real exchange rates since Ireland's entry into the ERM in 1979. In all three instances, real shocks account for major proportions of the variance of both the nominal and the real exchange rate. Consistent with our conjecture, the absolute variability of the punt-sterling rate is, however, well below that of the other two rates. 


\section{References}

Bayoumi, T. and Macdonald, R. (1998). "Deviations of Exchange Rates from Purchasing Power Parity: A Story Featuring Two Monetary Unions,” CEPR Discussion Paper Series No. 1932.

Chen, L. and Devereux, J. (1999). "What Can U.S. City Price Data Tell Us about PPP," unpublished paper, Queens College, CUNY, Flushing N.Y.

Culver, S.E. and Papell, D. (1999). "Panel Evidence of Purchasing Power Parity Using Intranational and International Data," unpublished paper, University of Houston.

Diebold, F.X., Husted, S. and Rush, M. (1991). "Real Exchange Rates under the Gold Standard," Journal of Political Economy, Vol. 99, no. 6, pp. 1252-1271.

Edison, H., Gagnon, J.E. and Melick, W.R. (1997) "Understanding he Empirical Literature on Purchasing Power Parity: The Post-Bretton Woods Era," Journal of International Money and Finance, Vol. 16, No. 1, pp. 1-17.

Engle, C. and Rogers, J. (1995). "How Wide Is the Border?" NBER Working Paper No. 4829.

Engle, R.F. and Granger, C. W.J. (1987). Cointegration and Error Correction: Representation, Estimation and Testing, Econometrica, Vol. 55, No. 2, pp. 251-276.

Fitzgerald, J. and Shortall, F. (1998). "Pricing to Market, Exchange Rate Changes and the Transmission of Inflation," The Economic and Social Review, Vol. 29, No. 4, pp. 323-340.

Fountas, S. and Wu, J. (1995). "PPP and the Irish Experience," Kredit und Kapital, Vol. 28, No. 2. , pp. 201-215.

Froot, K., Kim, M. and Rogoff, K. (1995). "The Law of One Price Over 700 Years," NBER Working Paper No. 5132.

Froot, K., and Rogoff, K. (1995). "Perspectives on PPP and the Long-Run Real Exchange Rate," in Gene Grossman and Kenneth Rogoff (eds), The Handbook of International Economics, Amsterdam, Elsevier.

Gallagher, L.A. and Kavanagh, E. (2000). “Irish Real and Nominal Exchange Rate Behaviour: The ERM Period," unpublished paper, University College Cork.

Honahan, P. (1997). "Currency Board or Central Bank? Lessons from the Irish Pound's Link with Sterling, 1928-79,” Banca Nazionale del Lavoro Quarterly Review, Vol. No. 200, pp. 39-67.

Johnson, D. R. (1993). "Unit Roots, Cointegration and Purchasing Power Parity: Canada and the United States, 1870-1991," in The Exchange Rate and the Economy. Ottawa, Bank of Canada.

Jorion, P. and Sweeney, R.J. (1996). "Mean Reversion in Real Exchange Rates," Journal of International Money and Finance, Vol. 15, No. 4, pp. 535-550.

Leddin, A. and O'Leary, J. (1995). "Fiscal, Monetary and Exchange Rate Policy," in J. W. O' Hagan, ed., The Economy of Ireland: Policy and Performance of a Small European Economy, Dublin: Gill and Macmillan, Ltd.

Lothian, J.R. (1990). “A Century Plus of Japanese Exchange Rate Behaviour,” Japan and the World 
Economy, Vol. 2, pp. 47-70.

Lothian, J.R. (1998a). "Some New Stylized Facts of Floating Exchange Rates," Journal of International Money and Finance, Vol. 17, No. 1, pp. 29-40.

Lothian, J. R., (1998b). "Movements in Exchange Rates and Relative Price Levels in the Netherlands and Britain over the Past Four Centuries," unpublished paper Fordham University.

Lothian, J.R. and Taylor, M.P. (1996). "Real Exchange Rate Behaviour: The Recent Float from the Perspective of the Past Two Centuries," Journal of Political Economy, Vol. 104, No. 3, pp. 488509.

Lothian, J.R. and Taylor, M.P. (2000). " Purchasing power parity over two centuries: strengthening the case for real exchange rate stability. Reply to Cuddington and Liang," Journal of International Money and Finance, Vol. 19, No. 5, 759-764 .

Lucas, R.E. Jr. (1982). "Interest Rates and Prices in a Two-Currency World," Journal of Monetary Economics, Vol. 10, No. 3, pp. 335-360.

Mitchell, B. R., (1975). European Historical Statistics, 1750-1970. New York: Columbia University Press.

Mussa, M. (1986). "Nominal Exchange Rate Regimes and the Behaviour of Real Exchange Rates: Evidence and Implications," Carnegie-Rochester Conference Series on Public Policy, Vol. 25, pp. $117-214$.

ó Gráda, C. (1994). Ireland: A New Economic History, 1780-1939, Oxford, Clarendon Press.

ó Gráda, C. and O’Rourke, K. (1994) “Ir ish Economic Growth, 1945-1988,” Center for Economic Policy Research, Discussion Paper 975.

Rogoff, K. (1996). “The Purchasing Power Parity Puzzle,” Journal of Economic Literature, Vol. 33, No. 2, pp. 647-667.

Taylor, A. (1996). "International Capital Mobility in History," unpublished working paper, Northwestern University.

Taylor, M.P. (1995). "The Economics of Exchange Rates," Journal of Economic Literature, Vol. 33, No. 1, pp. 13-47.

Thom, R. (1989). "Real Exchange Rates, Cointegration and Purchasing Power Parity: Irish Experience in the EMS, The Economic and Social Review, Vol. 20, No.2, pp. 147-163.

Wright, J.H. (1993). "Quantifying the Non-Stationarity in Irish Real Exchange Rates," The Economic and Social Review, Vol. 25, No. 1, pp. 109-119.

Wright, J.H. (1994). "A Co-integration Based Analysis of Irish Purchasing Power Parity Relationships Using the Johansen Procedure," The Economic and Social Review, Vol. 25, No. 3, pp. 261-278. 
Fig. 1. Real exchange rate and prices, Ireland vs. UK

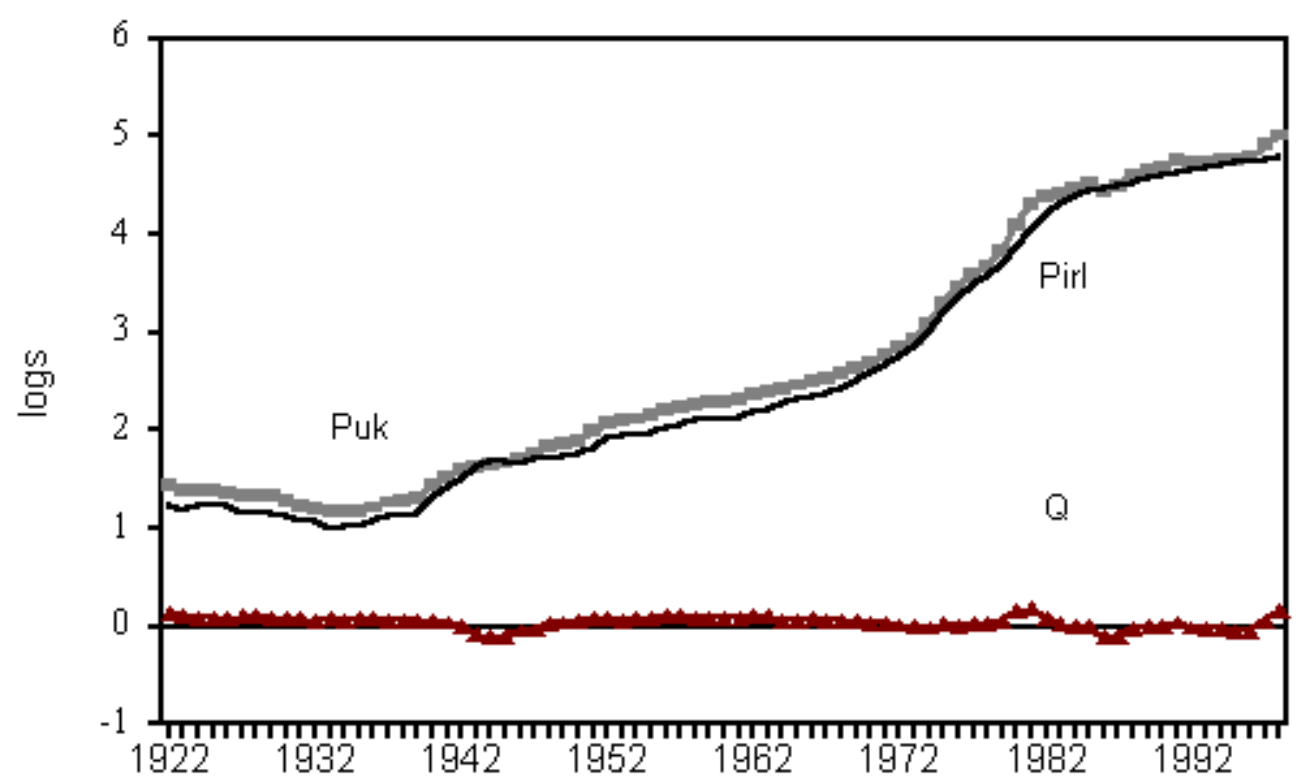

Fig.2. Real exchange rate and prices, Ireland vs. Germany

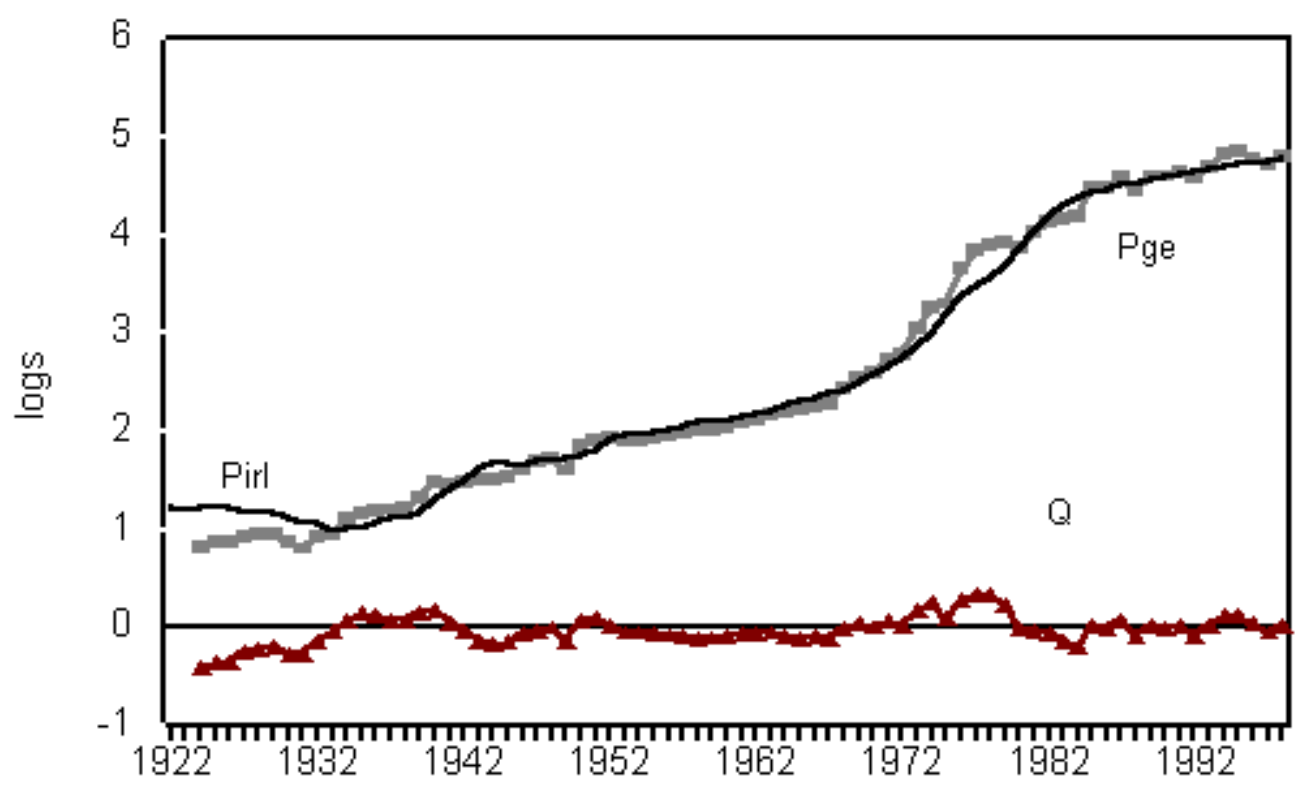


Fig. 3. Real exchange rate and prices, Ireland vs. US

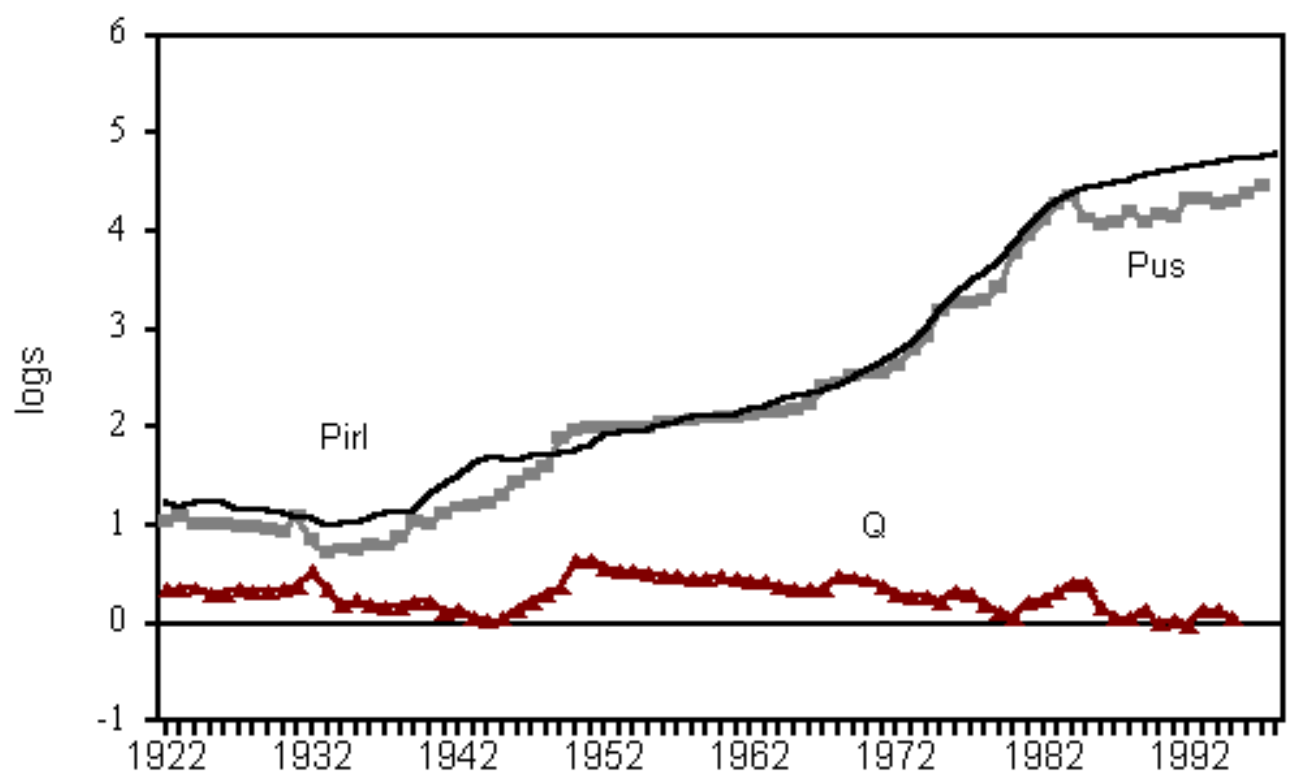


Figure 4a. Punt-Sterling: Components real exchange rate variance

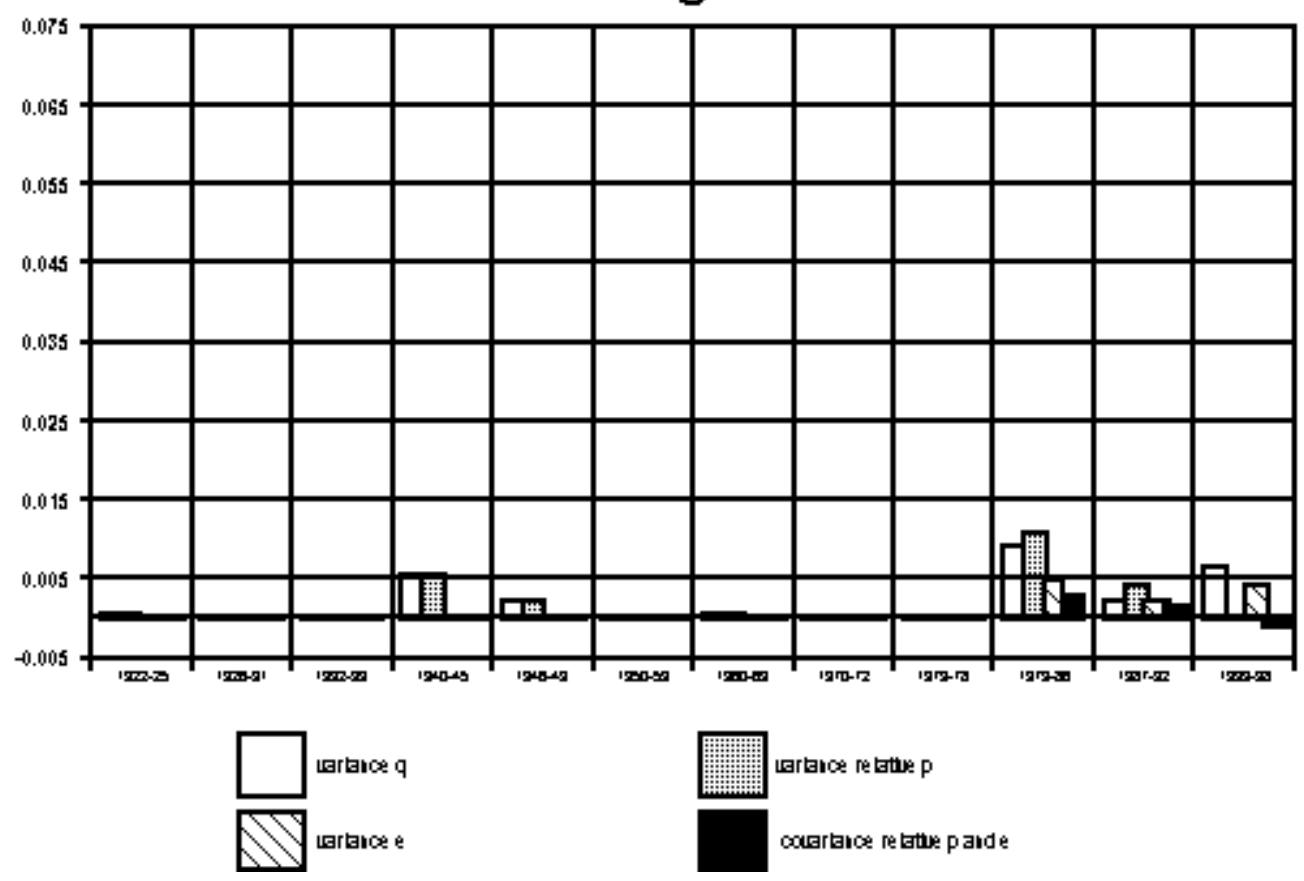

Figure 4b. Punt-Dollar: Components real exchange rate variance

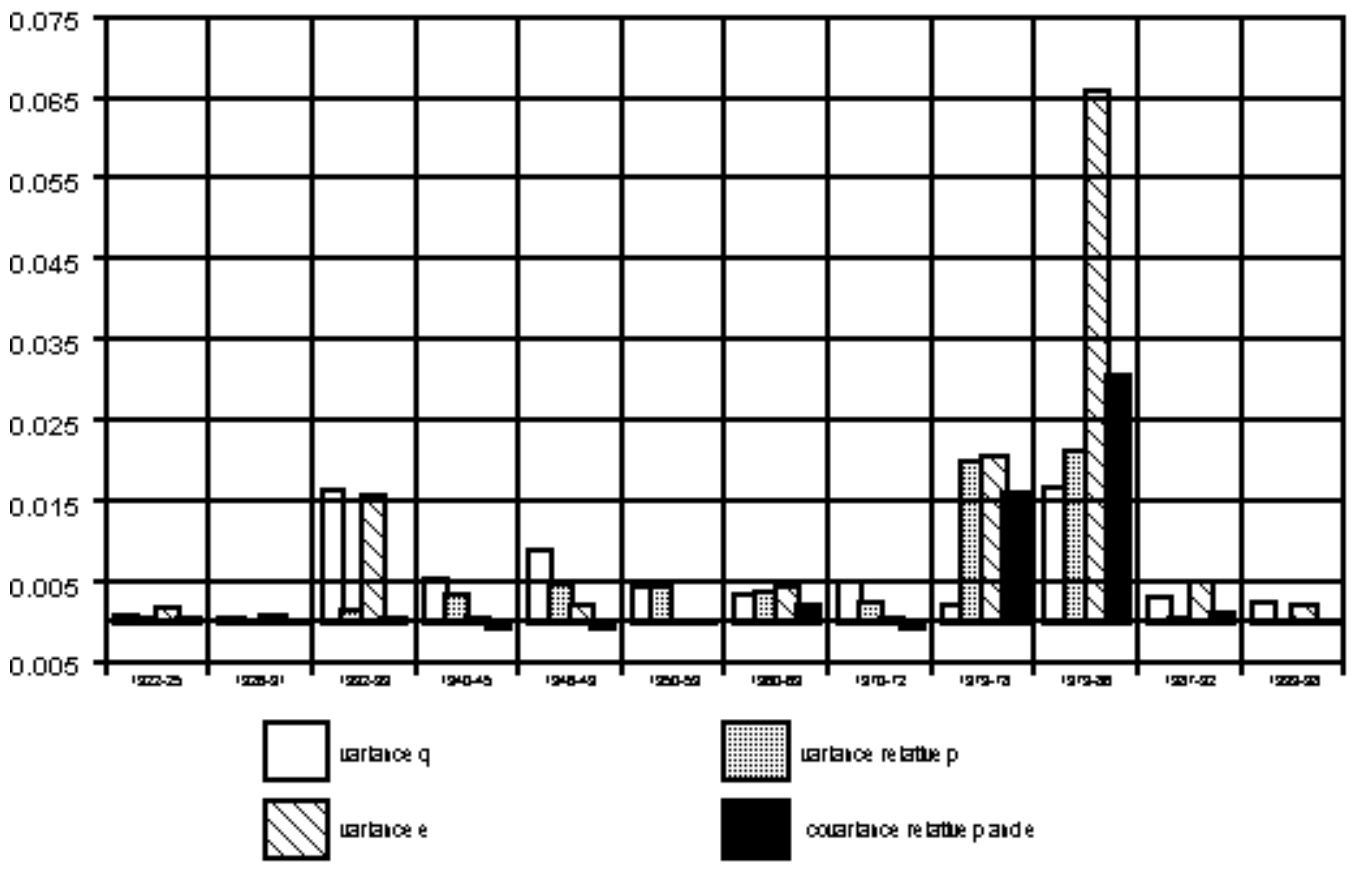


Figure 4c. Punt-DM: Components real exchange rate variance

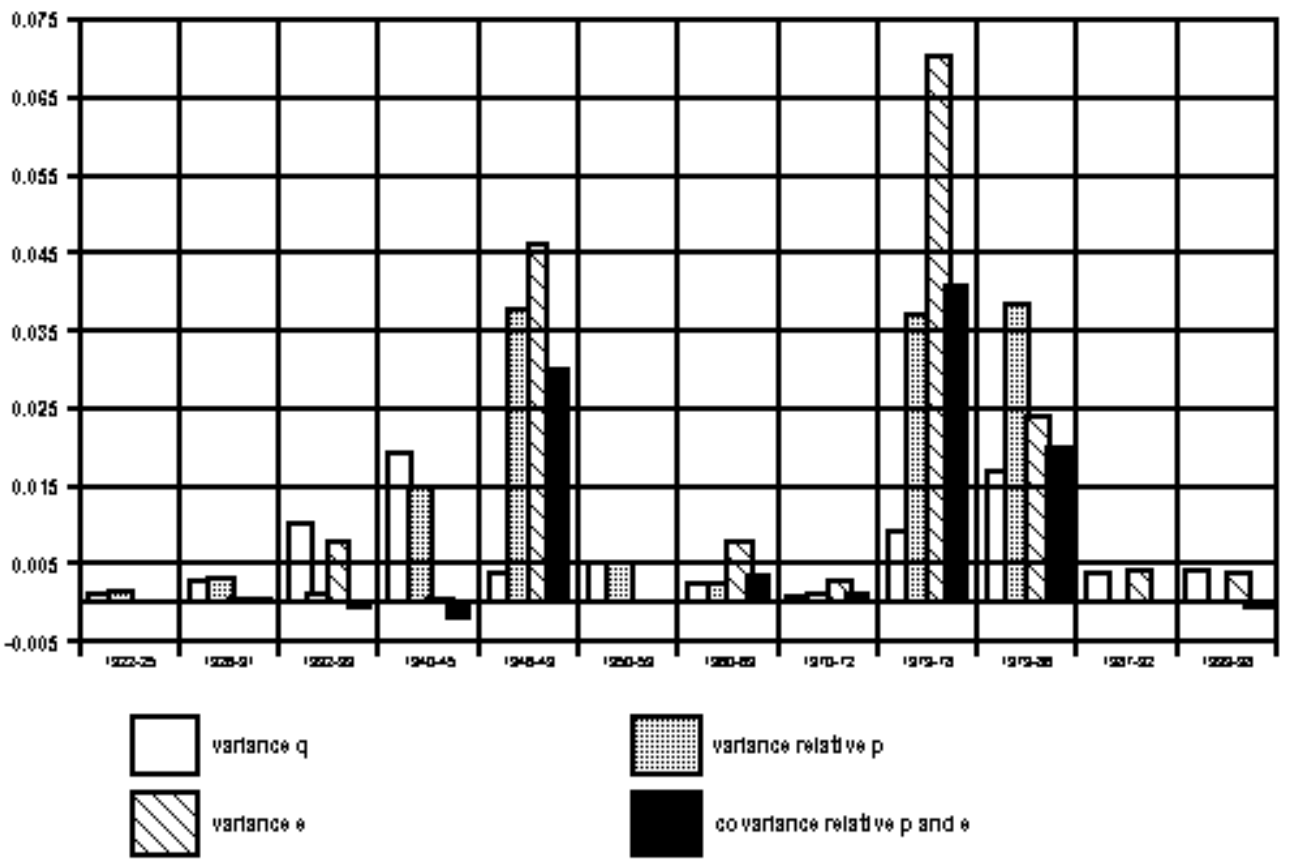


Table 1. Summary statistics

\begin{tabular}{|c|c|c|c|c|c|c|c|c|}
\hline & & $\mathrm{p}_{\mathrm{IRL}}$ & $\mathrm{pa}_{\mathrm{UK}}$ & $\mathrm{pa}_{\mathrm{US}}$ & $\mathrm{pa}_{\mathrm{GE}}$ & $\mathrm{q}_{\mathrm{UK}}$ & $\mathrm{q}_{\mathrm{US}}$ & $\mathrm{q}_{\mathrm{GE}}$ \\
\hline \multirow[t]{2}{*}{$1922-98$} & Mean & 2.546 & 2.666 & 2.328 & 1.658 & 0.047 & 0.288 & 0.016 \\
\hline & Std Dev & 1.300 & 1.281 & 1.241 & 1.351 & 0.061 & 0.160 & 0.147 \\
\hline \multirow[t]{2}{*}{$1922-30$} & Mean & 1.190 & 1.362 & 1.020 & -0.011 & 0.098 & 0.336 & -0.288 \\
\hline & Std Dev & 0.036 & 0.044 & 0.038 & 0.052 & 0.018 & 0.022 & 0.080 \\
\hline \multirow[t]{2}{*}{$1931-38$} & Mean & 1.064 & 1.209 & 0.836 & 0.167 & 0.072 & 0.278 & 0.011 \\
\hline & Std Dev & 0.048 & 0.042 & 0.124 & 0.156 & 0.013 & 0.133 & 0.142 \\
\hline \multirow[t]{2}{*}{$1939-50$} & Mean & 1.583 & 1.652 & 1.285 & 0.663 & -0.005 & 0.207 & -0.013 \\
\hline & Std Dev & 0.194 & 0.175 & 0.283 & 0.139 & 0.065 & 0.168 & 0.120 \\
\hline \multirow[t]{2}{*}{$1951-72$} & Mean & 2.223 & 2.372 & 2.168 & 1.281 & 0.075 & 0.451 & -0.035 \\
\hline & Std Dev & 0.252 & 0.234 & 0.196 & 0.272 & 0.025 & 0.083 & 0.060 \\
\hline \multirow[t]{2}{*}{$1973-98$} & Mean & 4.188 & 4.282 & 3.856 & 3.345 & 0.021 & 0.174 & 0.064 \\
\hline & Std Dev & 0.599 & 0.592 & 0.555 & 0.521 & 0.070 & 0.118 & 0.140 \\
\hline \multirow[t]{2}{*}{$1973-78$} & Mean & 3.255 & 3.343 & 3.010 & 2.597 & 0.015 & 0.262 & 0.250 \\
\hline & Std Dev & 0.279 & 0.293 & 0.272 & 0.348 & 0.016 & 0.047 & 0.095 \\
\hline \multirow[t]{2}{*}{$1979-86$} & Mean & 4.180 & 4.304 & 4.003 & 3.258 & 0.051 & 0.241 & -0.015 \\
\hline & Std Dev & 0.285 & 0.228 & 0.324 & 0.229 & 0.096 & 0.130 & 0.130 \\
\hline \multirow[t]{2}{*}{$1987-92$} & Mean & 4.588 & 4.651 & 4.127 & 3.676 & -0.010 & 0.045 & -0.004 \\
\hline & Std Dev & 0.060 & 0.098 & 0.052 & 0.065 & 0.047 & 0.055 & 0.063 \\
\hline \multirow[t]{2}{*}{ 1993-98 } & Mean & 4.734 & 4.823 & 4.353 & 3.878 & 0.016 & 0.125 & 0.051 \\
\hline & Std Dev & 0.037 & 0.109 & 0.058 & 0.080 & 0.080 & 0.048 & 0.064 \\
\hline
\end{tabular}

Note: All variables are in $\log$ form. $\mathrm{p}_{\mathrm{IRL}}$ is the price level for Ireland, $\mathrm{pa}_{\mathrm{i}}$ is the exchange-rate adjusted price level for country $i$ and $\mathrm{q}_{\mathrm{i}}$ is the Irish-country $\mathrm{i}$ real exchange rate. 
Table 2. Regressions to test for differences in variability of real exchange rates across nominal exchange rate regimes

\begin{tabular}{rrrrr}
\hline Constant & DFIXED & DUNION & DWWII & $\mathrm{R}^{2} / \mathrm{SEE}$ \\
\hline 0.081 & -0.023 & -0.034 & & 0.361 \\
11.16 & -2.000 & -2.576 & & 0.029 \\
& & & & \\
0.076 & -0.018 & -0.038 & 0.038 & 0.431 \\
10.64 & -1.646 & -3.036 & 2.245 & 0.027 \\
\hline
\end{tabular}

Note: The dependent variable is a pooled series of the standard deviations of the punt-sterling, punt-dollar and punt-DM real exchange rate for the periods: $1922-25,1926-31,1932-39,1940-45$, 1946-49, 1950-59, 1960-69, 1970-72, 1973-78, 1979-86. 1987-92 and 1993-98. DFIXED is a dummy variables for all fixed-rate periods including the period of currency union between Ireland and the UK; , DUNION is a dummy for the period of currency union alone; and DWWII is a dummy for World War II. Figures below the coefficients are $t$ values. 
Table 3. Unit root tests

\begin{tabular}{lllll}
\hline Series & Germany & UK & US & Ireland
\end{tabular}

PRICES

Log Levels

$\begin{array}{lllll}\text { ADF } & 0.707 & 0.337 & 0.577 & 0.183 \\ \text { P-P } & 0.641 & 1.666 & 0.799 & 1.305\end{array}$

First Differences

$\begin{array}{lllll}\text { ADF } & -8.120 & -3.697 & -6.129 & -3.338 \\ \text { P-P } & -8.144 & -3.532 & -6.124 & -3.214\end{array}$

REAL EXCHANGE

$\underline{\text { RATE }}$

Log Levels

$\begin{array}{llll}\text { ADF } & -3.401 & -3.566 & -2.143 \\ \text { P-P } & -3.402 & -3.078 & -2.321\end{array}$

First Difference

\begin{tabular}{llll} 
ADF & -8.785 & -6.371 & -7.421 \\
P-P & -8.811 & -6.271 & -7.351 \\
\hline
\end{tabular}

Note: The prices for Germany, UK and US are exchange-rate adjusted price levels. ADF is Augmented Dickey Fuller unit root test with the appropriate number of lagged differences determined by the BIC criterion. $\mathrm{P}-\mathrm{P}$ is Phillips-Perron unit root test with the window width set at 3 . The critical values for $.01, .05$ and .10 significance levels are $-3.52,-2.90$ and -2.59 , respectively. 
Table 4. Chow tests for floating-rate period shifts in real exchange rates

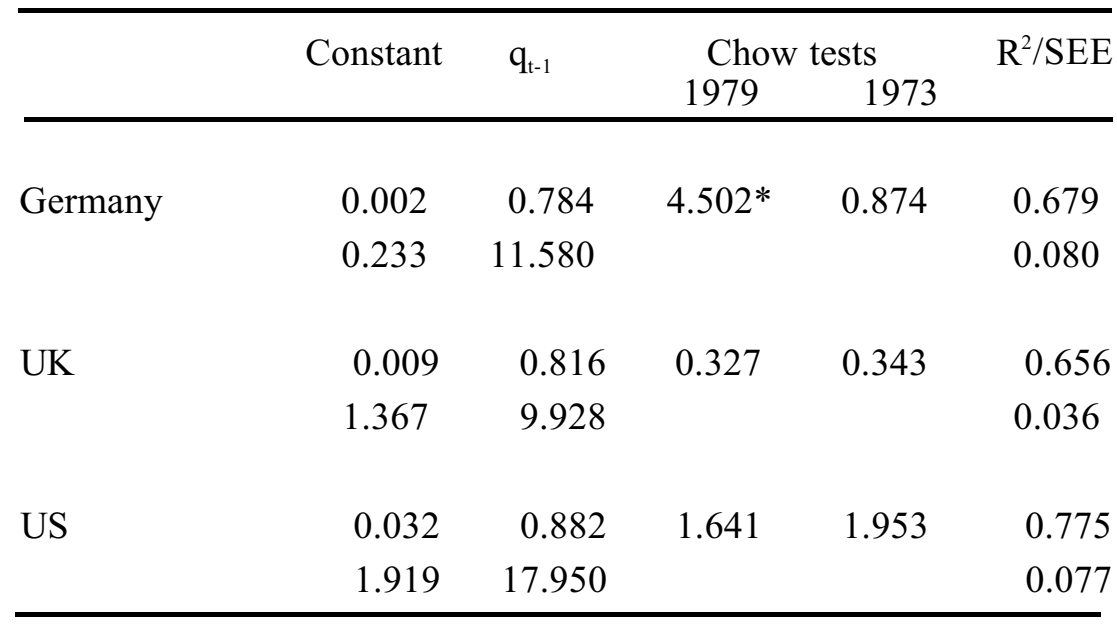

Note: The Chow tests are for significant shifts in intercepts and slopes in 1979 and 1973, respectively. Figures beneath the coefficients are $t$ values. Standard errors of estimate and t values were computed using White's heteroskedastic-consistent standard er rors. 
Table 5. Tests on the pooled real exchange rate data

\begin{tabular}{|c|c|c|c|c|c|c|c|c|}
\hline Constant & $\mathrm{DU}$ & DG & DFL & $\mathrm{q}_{\mathrm{t}-1}$ & $\mathrm{DU} \times \mathrm{q}_{\mathrm{t}-1}$ & $D G \times q_{t-1}$ & $\mathrm{DFL} \times \mathrm{q}_{\mathrm{t}-1}$ & E E \\
\hline 0.008 & 0.038 & -0.005 & & 0.836 & & & & 0.865 \\
\hline 1.713 & 2.831 & -0.424 & & 22.014 & & & & 0.067 \\
\hline 0.009 & 0.024 & -0.006 & & 0.816 & 0.065 & -0.033 & & 0.866 \\
\hline 1.367 & 1.320 & -0.552 & & 9.926 & 0.680 & -0.307 & & 0.067 \\
\hline 0.012 & & & & 0.915 & & & -0.051 & 0.860 \\
\hline 0.005 & & & & 0.026 & & & 0.081 & 0.068 \\
\hline 0.008 & 0.041 & -0.003 & & 0.842 & & & -0.078 & 0.866 \\
\hline 1.731 & 2.950 & -0.304 & & 22.329 & & & -0.925 & 0.067 \\
\hline-0.002 & 0.027 & 0.005 & 0.025 & 0.920 & -0.013 & -0.126 & -0.146 & 0.868 \\
\hline-0.222 & 1.399 & 0.343 & 1.402 & 8.478 & -0.111 & -1.014 & -1.290 & 0.067 \\
\hline
\end{tabular}

Note: DU and DG are dummy variables for the United States and Germany; DFL is a dummy variable for the floating-rate periods (1973-1998 in the case of the punt-dollar; 1973-79 in the case of the punt-DM and 1979-1998 in the case of punt-sterling). Figures beneath the coefficients are t values. Standard errors of estimate and t values were computed using White's heteroskedastic-consistent standard er rors. 